\title{
STUDI PEMETAAN DAKWAH DALAM \\ PENYULUHAN AGAMA
}

\author{
Aep Kusnawan \\ UIN SGD Bandung \\ email: aep kusnawan@uinsgd.ac.id
}

\begin{abstract}
Religious counselors are like doctors who will give medicine, so he must make a thorough diagnosis in order to have a picture of the right conditions, what diseases suffered by patients, what medications are right, and what level of health might be built with the drug.

Similarly, the extension of religion, if it is intended to improve the condition of society, it is necessary for him to start the activity by first knowing the objective condition of the object of da'wah, which then followed up with various activities of da'wah appropriate, effective and efficient. Efforts to determine the objective conditions mad'u it, the authors do through research mapping da'wah in Bandung.

This research was conducted on the academic community of Dakwah Faculty who actively conducted mapping of da'wah in Bandung. Using qualitative methods. Through interviewing techniques and documentation.

The results showed that mapping of da'wah is a very basic need in religious education activities. It is useful to facilitate the analysis of religious counseling objects, so that the counselor can properly present the
\end{abstract}


material, methods and media used in religious counseling, in accordance with the conditions and needs of the local community. With that mapping, religious counseling basically will not only shaped the message of Islamic teachings, but is moving towards religious social change.

Keywords: Mapping; Religious Counseling; Religious Social Change

\section{Pendahuluan}

Terjadinya perubahan sosial keagamaan ke arah kemajuan dengan pesat itu mencerminkan efektivitas pola perubahan sosial yang dilakukan. Ke-efektivan tersebut, jika didekati melalui istilah keilmuan yang berkembang dewasa ini, maka ia merupakan cermin dari kehebatan manajerial atau manajemen perubahan sosial yang diterapkan. Persoalannya, konsep manajemen yang bagaimana yang dimiliki dan terapkan oleh Nabi Muhammad SAW, sehingga ia mampu melakukan proses perubahan sosial, yang dipandang oleh banyak kalangan, ${ }^{1}$ berhasil dengan gemilang? Suatu kehebatan yang tercatat dalam catatan sirah, belum mampu dilanjutkan oleh generasi muslim setelahnya, bahkan hingga kini sekalipun.

Terkait dengan perubahan sosial keagamaan tersebut, dewasa ini sering muncul analisa dalam diskusi akademisi dakwah, bahwa saat ini banyak diselenggarakan kegiatan dakwah. Kegiatan itu antara lain, dilakukan di suatu wilayah oleh para penyuluh agama yang datang silih berganti,

1 Banyak ahli sejarah yang menyatakan kehebatan Nabi SAW dalam melakukan perubahan sosial masyarakat Arab dari yang tadinya jahiliyah menjadi masyarakat maju di tengah percaturan kawasan Arab. Pengakuan tersebut bukan hanya dari para sejarawan Islam tapi juga dari non-musli. Sekedar menyebut contoh Michael H. Hart, yang telah menempatkan Nabi SAW menjadi orang No. satu di dalam ranking bukunya. 
membahas apa yang berasal dari "pemahaman" para penyuluh agama.

Sementara penyuluh agama yang datang, jarang yang berkesempatan mencari tahu secara memadai siapa dan bagaimana kondisi madu-nya. Sehingga pesan yang disampaikan penyuluh agama, lebih dominan apa yang ada dipikiran penyuluh agama. Mad'u pun lebih diposisikan sebagai objek, yang suka ataupun tidak dan butuh ataupun tidak, harus menerima apa saja pesan yang disampaikan penyuluh agama.

Informasi pesan yang tidak memadai dimiliki penyuluh agama tentang mad'u, dipandang sementara pihak akan berdampak pada hasil dakwah ke depan yang tak akan mengalami perkembangan yang berarti, tak jelas arah, target, dan ukuran capaiannya. Sehingga apabila evaluasi dakwah diadakan, hasilnya tetap sulit terukur. (Asep S. Muhtadi dkk, 2004:29)

Maka wajar, jika kegiatan dakwah dewasa ini seperti diungkapkan Asep S. Muhtadi (Warta Al-Jamiah: 2010: 19), bahwa Dakwah tanpa Peta Ibarat Pizza yang bergizi tapi dimakan oleh orang yang terbiasa makan jagung, bisa dibilang engga enak dan berdampak mencret. Demikian hanya dakwah yang disampaikan oleh seorang Penyuluh agama belum tentu tepat, manakala tidak disesuaikan dengan apa yang dibutuhkan dan diperlukan oleh warga di suatu wilayah.

Sesuai dengan alur pemaparan di atas, maka tulisan ini hendak mencari jawaban atas sejumlah pertanyaan mengenai sejumlah pertanyaan, kepada para civitas akademika Fakultas Dakwah dan Komunikasi, yang aktif melakukan pemetaan dakwah.

Pertama, Bagaimana studi pemetaan dakwah dilakukan? Kedua, Apa saja alat pengumpulan data untuk pemetaan dakwah? Ketiga, Bagaimana analisa pemetaan 
dilakukan? Keempat, bagaimana signifikansi pemetaan bagi perubahan sosial keagamaan

\section{Konsep Pemetaan Dakwah}

Secara kewilayahan, dakwah berhadapan dengan berbagai macam situasi dan kondisi. Secara lingkungan geografis ada pegunungan, pedalaman, perkebunan, pesisir, pedesaan, transisi, perkotaan, metropolitan, megapolitan, marginal dan guru. Secara lingkungan ekonomis, ada masyarakat produksi, masyarakat distrubusi, masyarakat konsumen, miskin, menengah kaya. Secara lingkungan sosial, ada lingkungan perumahan, real estate, dan perkampungan. (J.B.A.F. Mayor Folak, 1976:53)

Secara lingkungan keagamaan, ada masyarakat total Islam, masyarakat mayoritas Islam, masyarakat sebanding dan masyarakat ninoritas Islam. Secara lingkungan aliran pemikiran keagamaan, ada ragam masyarakat aliran theologi, aliran fiqh, aliran tasawuf, aliran gerakan dakwah, dan sebagainya. (Sidi Ghazalba, 1983:155)

Secara kolompok masyarakat, Kemenag (2009:13) telah memberikan langkah identivikasi (awal) mengenai ragam sasaran dakwah. Berdasarkan ragam sasaran dakwah kemasyarakatan, Kemenag mengidentivikasi beragam kelompok masyarakat yang menjadi sasaran dakwah. Misalnya: Kelomp. Generasi Muda/Remaja Kelomp. Generasi Tua: Rima/ Ema, Kelomp. Ibu-ibu, Kelomp. Bapa-Bapak, Kelompok Anak-anak, Kelmp. Masy. Industri, Kelmp. Masy. Daerah Rawan, Kelmp. Transmigran, Kelomp. Masy. Suku Terasing, Komp. Perumahan, Kelmp. Masy Kampus, Kelomp. Kary. Pemerintah, Kelomp. Kary. Swasta, Kelomp Pejabat, Kelomp. Masy. Industri, Kelomp. Masy. Gelandangan, Kelompk. Masya. Pengemis, Kelompk Masy. Desa, Kelompk Masy Buruh, Kelompok Masy Petani, Kelompok Masy Nelayan, Kelompok Artis, Kalangan Tuna Susila, Kelompok 
Anak Jalanan, Kelompok Pengamen, Kalangan Underground, Kelomp. Masy. Pasar, Kelompk Masy. Terminal, Penumpang Bis Wisata, Penumpang Pesawat, Penumpang Kapal Laut, di Rumah Sakit, di Hotel, di Tempat Wisata, dan sebagainya.

Kondisi wilayah objek dakwah yang beragam tersebut memerlukan bantuan manajerial. Karena manajemen merupakan pembantu seseorang dalam memecahkan masalahmasalah yang hadapi manusia, khususnya dalam mengupayakan efektivitas dan efisiensi apa yang diperbuatnya. Sesuai dengan pendapat GR Terry, ${ }^{2}$ bahwa manajemen adalah: a distinct process consisting of planning, organizing, actuating, and controling, performed to determine and a complish stated objektives by the use of human beings and other resources. Dengan kata lain, manajemen ialah suatu proses penetapan dan pencapaian tujuan-tujuan tertentu melalui proses: (1) perencanaan (planning), (2) pengorganisasian (organizing), (3) pelaksanaan (actuating)dan pengendalian (controling), dengan memanfaatkan manusia dan sumber daya yang lainnya.

Dalam manajemen di atas, aspek perencanaan ternyata menempati posisi strategis. Perencanaan dapat memberikan kejelasan arah kegiatan. Kegiatan yang terarah dapat dilaksanakan lebih efektif dan efisien. Perencanaan dapat mengarahkan institusi Dakwah Islam menuju tujuan yang tepat dan benar menurut tujuan institusi itu sendiri. Artinya perencanaan memberi arah bagi ketercapaian tujuan sebuah sistem, karena pada dasarnya sistem akan berjalan dengan baik jika ada perencanaan yang matang.

Perencanaan secara ringkas berarti "Suatu rangkaian proses kegiatan menyiapkan dan menentukan seperangkat keputusan mengenai apa yang diharapkan terjadi dan apa yang akan dilakukan". ${ }^{3}$ 
Dengan kata lain yang dimaksud dengan perencanaan Dakwah adalah suatu proses intelektual yang berkesinambungan dalam menganalisis, merumuskan, dan menimbang serta memutuskan dengan keputusan yang diambil mempunyai konsistensi (taat asas) internal yang berhubungan secara sistematis dengan keputusan lain dalam pembangunan, baik dalam bidangnya maupun dalam bidang lain. Untuk suatu jenis kegiatan ia tidak ada batas waktu, serta tidak harus selalu satu kegiatan mendahului dan didahului oleh kegiatan lain.

Ada beberapa tahapan dalam perencanaan dakwah. Salah satu rumusannya dapat dikembangkan dalam pengembangan dakwah Islam, sebagaimana dikemukakan oleh Banghart \& trull (1973), yang dikutip oleh Udin S. Saud dan Abin S. Makmun, ${ }^{4}$ sebagai berikut: Identifying educational planning problems. Mencakup beberapa tahap yaitu: pertama, delineating the scope of educational problem, atau menentukan ruang lingkup permasalahan perencanaan. Kedua, studying what has been, atau mengkaji apa yang telah direncanakan. Ketiga, determining what has been versus what should be, yang artinya membandingkan apa yang telah dicapai dengan apa yang seharusnya dicapai. Keempat, resources and contrains atau sumber daya yang tersedia dan ketercatannya. Kelima, establishing educational planning parts and priorities artinya mengembangkan bagian-bagian perencanaan dan prioritas perencanaan.

Langkah perencanaan yang demikian, dalam hal ini erat kaitannya dengan kegiatan pemetaan. Suatu kegiatan yang apabila dikaitkan dengan dakwah, maka ia menjadi pemetaan dakwah.

3 Dalam bahasa agama, perencanaan lebih kurang sama dengan niat. Menurut hadits, "setiap amal tergantung pada niatnya..."HR BukhariMuslim. Setiap kegiatan 50\% tergantung kepada perencanannya. Lihat, Aep Kusnawan (2009), Manajemen Pelatihan Dakwah, Jakarta: Rineka Cipta. 4 Ibid, h. 23-24. 
Studi pemetaan dakwah terkait dengan kebutuhan pemahaman penyuluh agama mengenai konsisi objek dakwah secara lebih detail dan spesifik. Ibarat dokter, untuk mengobati pasiennya, dengan obat yang tepat, maka dibutuhkan diagnosa yang tepat dan akurat pula. Tanpa dagnosa yang tepat, kemungkinan tidak tepatnya resep obat yang diberikan, tentu amat besar. Demikian halnya dalam melakukan kegiatan dakwah, dibutuhkan adanya "diagnosa" objek dakwah yang akurat, melalui studi pemetaan dakwah.

\section{Pembahasan}

Dari penelitian yang dilakukan memperoleh hasil sebagai berikut:

Pertama, Studi Pemetaan Dakwah. Studi pemetaan dakwah (SPD) tidak lain dari studi yang khusus mengenai kondisi objek. SPD adalah suatu studi yang diadakan dalam rangka mengumpulkan dan menganalisa gejala-gejala atau keterangan yang dapat menunjukan adanya kekurangan dalam hal pengetahuan, sikap, prilaku calon mad'u (objek dakwah), sehingga selanjutnya dapat memberi arah kepada para dai mengenai apa yang secara objektif dibutuhkan oleh madu. Sehingga kelak penyuluh agama dapat menyajikan materi yang cocok dengan masalah yang sedang dihadapi madu-nya.

Dalam praktinya SPD merupakan upaya menanyakan, mencari dan menemukan gambaran apa adanya mengenai kondisi objek dakwah serta menggambarkannya menjadi peta yang kelak dapat digunakan untuk penyajian "menu" dakwah yang tepat, sesuai skala peroritas apa yang dibutuhkan beragam objek dakwah untuk perubahan mereka menjadi lebih baik, menuju kondisi ideal.

Secara lebih spesifik, SPD yang dilakukan adalah: Pertama, sebagai upaya mengumpulkan informasi yang berkaitan dengan pengetahuan, dan prilaku mad'u saat ini yang diperlukan untuk merealisasikan keberislaman. Kedua, sebagai 
upaya mencari tahu gambaran apa adanya serta mengidentifikasi gap antara pengetahuan, keterampilan, dan prilaku saat ini dengan kebutuhan akan pengetahuan, dan prilaku yang seharusnya untuk melakukan keberislaman. Ketiga, sebagai langkah pengumpulan bahan untuk membuat ragam kondisi mad'u yang digambar berbentuk peta. Ketiga, sebagai acuan merumuskan tujuan dakwah dan isi materi dakwah.

Adapun tujuan SPD sendiri adalah untuk: Pertama, memperoleh mad'u yang tepat sesuai dengan tujuan kegiatan dakwah. Kedua, memperoleh rumusan hasil yang akan dicapai. Ketiga, memperoleh gambaran tentang masalah dan hambatan yang bisa diatasi melalui dakwah. Keempat, memperoleh gambaran tentang potensi dan sumber daya yang bisa ditingkatkan melalui kegiatan dakwah. Kelima, memperoleh gambaran metode dan media yang sesuai bagi mad'u. Keenam, memperoleh gambaran materi atau pokok-pokok bahasan yang tepat sesuai skala perioritas dakwah.

\section{Kedua, Teknik Pengumpulan Data Pemetaan}

Dakwah. Kegiatan pengumpulan data dalam kegiatan SPD dilakukan melalui berbagai teknik. Layaknya kegiatan penelitian, teknik pengumpulan data SPD dapat dilakukan melalui wawancara, survey, diskusi kelompok, laporan kelompok, maupun teknik dokomentasi.

Adapun data-data yang diperlukan dalam SPD untuk membuat pemetaan dakwah, antara lain menyangkut:

1. Data mengenai luas wilayah dan batas-batasnya.

2. Data mengenai kependudukan: Jumlah penduduk, tingkat kepadatan penduduk, kepenganutan agama, tingkat pendidikan, tingkat ekonomi, pemilihan politik, d11

3. Data mengenai prasarana dan sarana: Jalan, pasar, pertokoan, pesawahan perkebunan, sekolah, rumah 
sakit, puskesmas, madrasah, pesantren, masjid, sarana olah raga, sarana kesenian.

4. Data menganai kondisi sosiologis: Pranata sosial, organisasi sosial, kesadaran lingkungan, khazanah tadisi, norma dan tatakrama, pranata hukum, kepemimpinan, kontrol sosial, tantangan yang dihadapi.

5. Data mengenai kondisi masyarakat sasaran dakwah: pandangan hidup, indeks pembangunan manusia, pemahaman keagamaan, madzhab keagamaan, pengalaman keagamaan, ormas keagamaan, watak etnik, relasi antar etnik, budaya luhur, kepribadian, interaksi sosial, gaya hidup, etos kerja, sistem pembagian tugas, sistem kerjasama.

6. Data mengenai keadaan mitra penyuluh agama: Jumlah penyuluh agama, latar belakang pendidikan para penyuluh agama, latar belakang sosio budaya penyuluh agama, kondisi ekonomi penyuluh agama, orientasi politik penyuluh agama.

7. Data mengenai sejumlah potensi dan kekurangan di wilayah bersangkutan, dan sebagainya.

Data-data yang diperoleh selanjutnya ditampilkan dalam bentuk peta yang menggambarkan ragam kondisi wilayah dakwah tersebut. Peta dakwah dapat disusun secara manual dengan memanfaatkan peta buta yang ada. Selanjutnya peta buta tersebut diberi keterangan sesuai dengan keragaman kategori dan warna-warni potensi yang dimiliki wilayah terkait.

Ketiga, Analisa Data Pemetaan Dakwah. Semua data yang sudah diperoleh selama melakukan SPD dianalisa untuk dapat menemukan perioritas kebutuhan. Dari sejumlah masalah atau kebutuhan yang ditemukan dapat dipilih kebutuhan mana yang paling dirasakan mendesak untuk dipenuhi.

Dalam menyusun urutan-urutan prioritas kebutuhan umat terlibat secara aktif. Artinya bahwa umat yang mengetahui dan 
menentukan urutan-urutan masalah dan kebutuhan itu. Penelitian hanya mengrangsang umat untuk menyadari, memahami serta mungkin merumuskan masalah dan kebutuhan yang mereka butuhkan dan rasakan.

Ada paling tidak tiga norma untuk menentukan perioritas yaitu: Pertama, Kegawatanya. Besar kecilnya akibat (kerugian) untuk atau terhadap umat. Supaya lebih jelas sebaiknya dinyatakan dengan angka. Kedua, Mendesaknya. Dalam hal ini lebih menekankan soal waktu. Apabila tidak bisa ditunda lagi. Maka sedikit waktu, semakin dirasakan mendesak. Ketiga, Penyebaranya. Bagaiamana tingkat penyebarannya dari masalah tersebut, yaitu suatu masalah dapat mengakibatkan timbul masalah lain.

Ketika dakwah yang dilakukan terkait dengan misi perubahan, dakwah erat kaitannya dengan sejumlah pertanyaan awal, siapa? merubah apa? Di mana? Di mana yang terlebih dulu perlu diperioritaskan?

Misalnya pada wilayah letak kesatu, masyarakat yang belum melihat keperluan adanya dakwah, namun sudah ada pihak-pihak yang menggarap untuk kepentingan "perusakan" tatanan masyarakat. Area ini menjadi perioritas paling awal, karena umat perlu diselamatkan.

Pada letak wilayah kedua, masyarakat belum melihat adanya kebutuhan pada dakwah. Para tokoh agama juga belum melirik area tersebut sebagai area yang digarapnya. Bagi area tersebut menjadi perioritas kedua.

Pada letak wilayah ketiga, masyarakat sudah menunjukan peminatan terhadap dakwah, namun belum ada tokoh agama yang serius menyentuhnya. Area ini menjadi prioritas ketiga penggarapan penyuluh agama.

Pada letak wilayah keempat, masyarakat sudah menginginkan layanan dakwah, sementara para tokoh agama yang melihat potensinya sudah mulai masuk. Meski demikian Penyuluh agama melihat area ini sebagai perioritas keempat, 
bila akan mengembangakan wilayah tugasnya ini, dengan cara bermitra dengan para tokoh agama tersebut.

Pada letak wilayah kelima, masyarakatnya sudah maju, mengamalkan QS, bisa jadi percontohan, dan SDM-nya banyak dan bisa menyuplai ke daerah lain. Ini merupakan wilayah garapan periotas kelima.

Dengan melihat kepada peta kebutuhan umat dan kepekaan pihak tokoh agama dalam memberikan layanan dakwah di atas, diharapkan para penyuluh agama bisa lebih strategis dalam melaksanakan tugas. Setidaknya bisa lebih menempatkan skala prioritas, dengan pilihan I, II, III, IV, V. Sebagai ilustrasi, gambaran pemetaan dakwah terkategori sebagai berikut:

Wilayah yang Warna Biru (Kategori 5): Sudah maju, mengamalkan QS, bisa jadi percontohan, dan SDMnya banyak dan bisa menyuplai ke daerah lain. Warna Hijau (Kategori 4): Sudah mandiri, memahami QS, pengamalan belum cukup, Ada SDM, namun SDMnya belum bisa menyuplai ke daerah lain. Warna Putih (Kategori 3): Belum mandiri, kurang pemahaman QS, kurang SDM dan masih membutuhkan bantuan. Warna Kuning (Kategori 2): Lemah, belum memahami Quran Sunah, Tidak ada SDM, sangat perlu perhatian. Warna Merah (Kategori 1): Bahaya, belum bisa BTQ, Tidak ada SDM, kondisi masyarakat rusak, banyak pihak yang merusak, sangat perlu perhatian mendesak.

\section{Kempat, Signifikansi Pemetaan Dakwah pada} Perubahan Sosial Keagamaan. Ragam warna yang tertera pada peta menjadi bahan untuk ditindaklanjuti. Ragam kondisi masyarakat yang tergambarkan, erat kaitannya dengan permasalah masing-masing wilayah serta memerlukan adanya pemecahan. Kebutuhan untuk memecahkan masalah ini merupakan faktor penting yang ikut menentukan pada kebutuhan dakwah bagi mereka. 
Maka dari pemetaan itu kegiatan dakwah sedang berjalan pada fungsinya melakukan perubahan sosial keagamaan. Melalui pemetaan ia mendapat arah untuk dibangun menjadi "sajian menu" dakwah yang sesuai. Mulai dari program dakwah, pembagian garapan dakwah, target dan ukuran penyelesaian dakwah, pelaksanaan dakwah, pengawasan, evaluasi dan pengukuran tingkat keberhasilan, pendataan capaian perubahan dari waktu ke waktu, aspek capaian yang belum tercapai, analisa faktor penunjang dan penghambat, serta rekomendasi untuk ditindaklanjuti pada periode berikutnya.

Materi dakwah yang merupakan menu sajian penyelenggara dakwah, didasarkan atas masalah atau harapan yang ditemukan dilapangan. Materi dakwah erat kaitannya dengan tujuan yang hendak dicapai, agar masalah atau harapan tersebut bisa diatasi melalui kegiatan dakwah yang diselenggarakan.

Oleh karena itu, penataan materi dakwah butuh penataan secara apik dan tepat. Disamping ia perlu dikaitkan dengan pencapaian tujuan dan sasaran dakwah, ia juga berkaitan dengan unsur dakwah lain. Seperti penyuluh agama, mad'u, metode, media, waktu, serta biaya. Untuk itu, maka penataan materi dakwah sebaiknya disusun dalam suatu kurikulum dakwah yang disesuaikan dengan kondisi setempat, menuju terjadinya perubahan madu kea rah yang lebih ideal.

Tidak jarang terjadi di lapangan dakwah, tujuan dan target dicampurkan. Padahal, tujuan merupakan pernyataan tentang maksud secara umum. Sedangkan sasaran lebih menyatakan tuntutan yang sfesifik dan menunjukan hasil yang akan dicapai melalui kegiatan dakwah.

Baik tujuan maupun target diungkapkan dalam bentuk apa yang menjadi garapan mad'u. Hal semacam ini sangat penting, karena ini merupakan sarana untuk bisa diadakan penilaian objektif terhadap hasil program dakwah. Tujuan dan 
target ini mencakup aspek hasil kerja dakwah yang hendak dicapai.

Pada prinsipnya target dakwah dapat digolongkan menjadi tiga kategori: Pertama, pengetahuan. Dakwah yang diselenggarakan bertujuan untuk meningkatkan pengetahuan para mad'u. Kedua, sikap. Dakwah yang diselenggarakan bertujuan untuk menghasilkan perubahan sikap pada diri mad'u. Ketiga, prilaku. Dakwah yang diselenggarakan merupakan tujuan meningkatan keterampilan para mad'u sehubungan dengan tugas keberislaman yang harus diselesaikan.

Ketiga hal ini tidak dapat dipisahkan satu sama lain dan ketiganya ada pada setiap kegiatan dakwah yang diselenggarakan. Kekurangan pada salah satu aspek akan menggagalkan tujuan dakwah secara keseluruhan.

Misalnya pengetahuan meningkat tetapi tidak disertai adanya perubahan sikap berarti tujuan dakwah belum tercapai. Pengetahuan meningkat, perubahan sikap terjadi, tetapi tidak diikuti dengan meningkatnya prilaku tetapi tujuan dakwah belum tercapai seluruhnya.

Target dakwah merupakan berdasar pada apa yang sedang dilakukan, serta apa yang sedang dilakukan oleh madu. Dakwah dapat dikatakan berhasil dengan efektif apabila apa yang dirumuskan di dalam target sesuai dengan apa yang dihasilkan dalam tahapan-tahapan dakwah yang diselenggarakan.

Dengan demikian adanya target dalam kegiatan dakwah merupakan sarana keberhasilan dakwah, (Asep S. Muhtadi, dkk, 2004: 29), yang mempunyai arti dan manfaat. Pertama, sebagai dasar menentukan apa yang harus dilakukan penyuluh agama selama berdakwah. Kedua, menjamin konsistensi penyusunan program. Ketiga, memudahkan komunikasi antara penyusun program dakwah dengan pihak yang berkepentingan. Keempat, merupakan kerangka dari sesuatu program dakwah. 
Kelima, membantu penyuluh agama memilih strategi untuk mencapai tujuan dakwah. Keenam, memudahkan penyuluh agama dalam menyusun bahan penilaian terhadap kemajuan mad'u selama mengikuti dakwah. Ketujuh, menghindari kemajuan konflik antar penyelenggaraan program dakwah. Kedelapan, membantu penyelenggara untuk menentukan program tindak lanjut dari program dakwah selanjutnya.

Melalui pemetaan, sosiologis wilayah dakwah dapat dikembangkan gambarnya sehingga menjadi social setting wilayah tugas dakwah. Sejumlah kegunaan peta dakwah tersebut apabila berhasil dirancang dapat bermanfaat secara signifikan bagi perubahan sosial keagamaan.

Pertama, ia akan berguna semacam pemandu jalan atau pijakan, penopang bagi para penyuluh agama untuk melakukan dakwah perubahan social keagamaan secara efektif dan fisien. Kedua, Peta Sosiologis antara lain berguna dalam merencanakan materi yang hendak disampaikan penyuluh agama yang disesuaikan dengan dengan kondisi objektif wilayah dakwah, baik menyangkut kondisi sosial statik, maupun kondisi sosial dinamiknya.

Ketiga, menyangkut metode dan media misalnya. Tentu berbeda antara metode dan media dakwah dikalangan pendidikan tinggi dan pendidikan rendah, atau antara masyarakat perkotaan dengan masyarakat pedesaan. Antara daerah dengan daerah lain pun memiliki seperangkat norma dan adat-istiadat yang beragam, yang menuntut keragaman materi, metode dan media, meskipun tujuannya sama, yaitu mendekatkan objek dakwah kepada Allah SWT, namun setiap wilayah memiliki jalannya sendiri untuk mencapai tujuan dakwahnnya.

Dengan kata lain, kegiatan dakwah akan mencapai sasaran manakala berlangsung sesuai dengan kondisi dan situasi masyarakat yang menjadi objek dakwah. Jika tidak ada pengetahuan yang memadai tentang kondisi dan situasi objek 
dakwah, akan menjadi sebab awal gagalnya kegiatan dakwah tersebut. Penyuluh agama akan terjebak pada kegiatan dakwah yang terpisah dan tidak nyambung dengan kondisi dan situasi masyarakat sasaran dakwah. Kondisi masyarakat yang dimaksud adalah kondisi internal masyarakat tersebut. Sedangkan yang dimaksud situasi masyarakat adalah keadaan faktor-faktor yang mempengaruhi keadaan internal masyarakat.

Peta sosiologis di atas juga untuk menghindari penyuluh agama dari buta budaya, yang dapat menghantarkan penyuluh agama pada posisi yang tidak tepat, sebelum ia melakukan kegiatan dakwah. Sedangkan ketidaktepatan pada awal kegiatan, akan menimbulkan ketidaktepatan pada langkah-langkah berikutnya.

Oleh karena itu pengetahuan tentang nilai-nilai maupun kearifan lokal akan menjadi bekal yang sangat bermanfaat untuk masuk ke relung-relung sosiologis dan psikologis mereka. Lebih lanjutnya, ia akan berguna untuk penyuluh agama guna mempersiapkan materi yang tepat, metode yang tepat, media yang tepat dan tujuan yang tepat. Sehingga dengan berbagai ketepatan di atas, kegiatan dakwah dapat berjalan secara konstruktif bagi bagi kemajuan masyarakat yang bersangkutan.

Pengetahuan penyuluh agama tentang IPM misalnya, akan berimplikasi pada penyampaian materi, metode dan media yang disampaikan. Begitu juga pengetahuan tentang tingkat pemahaman dan pengamalan agama, juga akan menjadi bekal yang penting bagi seorang penyuluh agama. Setidaknya ia akan mewaspadai penyampaian materi "sensitif" yang dapat menimbulkan ketegangan, jika materi tersebut disampaikan secara fulgar. Wawasan akan keragama pemahaman keagamaan dapat mengilhami dan mendorong penyuluh agama untuk menyampaikan materi dakwah yang lebih bersikap toleran dan penghargaan terhadap perbedaan, tanpa mengesampingkan aspek inti ajaran. 
Dengan demikian, wawasan dan pemahaman mengenai kondisi internal masyarakat sebagai sasaran dakwah menjadi sangat penting. Antara lain sebagai bahan pijakan dan pertimbangan pertama dalam menentukan materi, metode dan media yang relevan. Paling tidak hal itu menjadi relevan dengan apa yang diajarkan Nabi SAW: ajak bicaralah mereka sesuai dengan tingkat pemikiran mereka.

Sementara gambaran profil da'i di wilayah kerja penyuluh agama akan bermanfaat bagi para penyuluh dalam rangka mengembangkan kegiatan dakwah. Dengan cara ini penyuluh agama akan mengetahui profil da'i yang selama ini berkiprah di tengah masyarakat yang menjadi wilayah tugasnya. Sekaligus untuk mempelajari sejumlah keutamaan yang telah didedikasikan mereka kepada masyarakat dan mengetahui aspek-aspek apa yang masih belum tergarap atau masih lemah digarap oleh para penyuluh agama di sana.

Para da'i pada dasarnya adalah mitra para penyuluh agama. Dengan mengetahui profil da'i, maka penyuluh agama akan mengetahui berapa kekuatan jumlah mitra kerja mereka sebagai penyuluh agama. Potensi bidang apa saja yang menjadi keunggulan tiap da'i, apa saja kelemahan kemampuan yang dimiliki tiap da'i, kiprah apa saja yang telah mereka dedikasikan, dan aspek keislaman apa yang belum tergarap oleh mereka.

Dengan begitu penyuluh agama menjadi terbantu dalam aspek kuantitas SDM yang sama-sama menggarap pengembangan keagamaan di wilayah kerjanya. Kerjaan penyuluh agama menjadi teringankan dengan diketahui secara detail tentang profil para da'i di sana. Tinggal penyuluh agama mengadakan silaturahmi dengan mereka, mengadakan koordinasi, berbagi tugas dan peran, serta menjalin gerakan bersama untuk sama-sama membangun masyarakat, sesuai dengan ajaran Islam yang faktual dan ideal. 
Ibarat penyuluh agama punya kawan, maka pelaksanaan tugas dapat disinergikan dengan para da'i yang ada. Penyuluh agama tampil sebagai manager, yang siap untuk mencermati kondisi yang masih kurang dan perlu perhatian, berbagi tugas sesuai keahlian, mengisi yang masih kurang dan memperkuat yang telah ada, pelaksanaannya dipantau secara cermat, hasilnya dievaluasi dan dijadikan rekomendasi untuk perbaikan selanjutnya.

Dengan cara demikian, maka keberagamaan masyarakat di wilayah kerja penyuluh agama secara berkala akan menjadi lebih terukur keberhasilannya, dan menjadi tidak ada alasan jika seorang penyuluh agama diberi tugas dengan wilayah tugas yang luas, sementara di sana terdapat sejumlah ustadz, kiya'i atau sebutan para da'i lainnya.

Penyuluh agama sendiri, disamping terlibat pada kegiatan yang ada, juga lebih mengutamakan pada penggarapan aspek-aspek yang belum tergarap oleh para da'i yang ada. Jika diantara da'i yang ada memiliki keahlian dalam menggarap yang belum tergarap di suatu wilayah, maka penyuluh agama mengajaknya untuk bekerjasama memberikan perhatian pada peningkatan kondisi di wilayah tersebut.

Dengan demikian, penyuluh agama dapat menjadi fasilitator, negasiator dan penghubung antar wilayah dan antar garapan yang sebelumnya bisa jadi belum tergarap. Sehingga dengan SDM yang ada, dan dengan sistem berbagi peran dan saling memberi kontribusi, kondisi wilayah akan terus meningkat, tanpa penyuluh agama terlalu repot melakukannya sendirian.

\section{Simpulan}

Pertama, Studi pemetaan dakwah (SPD) dilakukan di Bandung adalah dengan mengumpulkan informasi, mencari kesenjangan, pengumpulan bahan untuk membuat ragam kondisi mad'u yang digambar berbentuk peta, menjadikan peta 
sebagai acuan kegiatan dakwah. Adapun Tujuan SPD adalah untuk memperoleh gambaran kondisi mad'u yang tepat, memperoleh rumusan hasil yang ingin dicapai dari kegiatan dakwah, memperoleh gambaran tentang masalah dan hambatan yang bisa diatasi melalui dakwah, memperoleh gambaran tentang potensi dan sumber daya yang bisa ditingkatkan melalui kegiatan dakwah, memperoleh gambaran metode dan media yang sesuai bagi mad'u, serta memperoleh gambaran materi atau pokok-pokok bahasan yang tepat sesuai skala perioritas dakwah.

Kedua, Kegiatan SPD dilakukan melalui berbagai teknik, yaitu melalui wawancara, survey, diskusi kelompok, laporan kelompok, maupun teknik dokomentasi.

Ketiga, Analisa pemetaan dilakukan dengan mengkaji perioritas kebutuhan, dilihat dari kegawatanya, besar kecilnya akibat (kerugian) untuk atau terhadap umat, tingkat kemendesaknya, serta penyebaranya.

Keempat, Signifikansi pemetaan dakwah pada perubahan sosial keagamaan adalah: (1) Sebagai dasar menentukan apa yang harus dilakukan oleh penyuluh agama selama berdakwah. (2) Menjamin konsistensi penyusunan program. (3) Memudahkan komunikasi antara penyusun program dakwah dengan pihak yang berkepentingan. (4) Membantu penyuluh agama dalam mendesai materi, metode dan media dakwah yang sesuai dengan kondisi objektif wilayah dakwah. (5) Membantu penyuluh agama memilih strategi untuk mencapai tujuan dakwah. (6) Memudahkan penyuluh agama dalam menyusun bahan penilaian terhadap kemajuan mad'u selama mengikuti dakwah. (7) Menghindari kemajuan konflik antar penyelenggaraan program dakwah. (8) Membantu penyelenggara untuk menentukan program tindak lanjut dari program dakwah selanjutnya.

\section{Rekomendasi}


Akhirnya dakwah yang bernuansa perubahan sosial keagamaan, menggaris bawahi pentingnya pemetaan dakwah, karena pelaksanaan dakwah membutuhkan kejelasan kondisi wilayah dan sasaran. Pemetaan juga memudahkan penyuluh agama untuk membaca wilayah dan sasaran Dakwah dengan relatif cepat dan tepat. Memudahkan pemilahan objek berdasarkan keragaman masing-masing. Memudahkan penyajian materi, metode, media yang disesuaikan dengan kondisi sasaran. Mempermudah pencapaian skala prioritas dan target, serta pengembangan sebaran kegiatan dakwah.

Penyususnan pemetaan yang secara simultan dapat dibuat mulai dari penggambaran ragam potensi wilayah, termasuk masalah dan penyebabnya, kemudian ditentukan solusinya, berlanjut jadi program dakwah, pembagian garapan dakwah, target dan ukuran penyelesaian dakwah, pelaksanaan dakwah, pengawasan, evaluasi dan pengukuran tingkat keberhasilan, pendataan capaian perubahan dari waktu ke waktu, aspek capaian yang belum tercapai, analisa faktor penunjang dan penghambat, serta rekomendasi untuk ditindaklanjuti pada periode berikutnya.

Bila langkah itu dilakukan, maka ada harapan dakwah sebagai gerakan perubahan sosial keagamaan dapat secara bertahap menampakan wujudnya. Itulah pentingnya diadakan proyek penyusunan peta dakwah oleh para pihak yang memiliki konsen terhadap peningkatan mutu dakwah Islam.

\section{Daftar Pustaka}

Achmad Charris Zubair, Dari Kematian ke Epistemologi Dakwah, Philosophy Press, Yogyakarta, 2001

Aep Kusnawan, Dimensi Ilmu Dakwah, Widya Padjadjaran, Bandung, 2009. 
-Manajemen Pelatihan Dakwah, Rineka Cipta,

Jakarta, 2009

"Dinamika Agama dalam Kehidupan

Dinamis", Artikel Media Indenesia, 21 Mei 2001

Aida Vitayala dkk. (Ed.). Dakwah Pembangunan di Indonesia.

Penerbit Pustaka Pembangunan Swadaya Nusantara, Jakarta, 1995

A Ilyas Ismail, Filsafat Dakwah: Rekayasa membangun Agama dan Peradaban Islam, Kencana, Jakarta, 2011

A Lysen, Individu dan masyarakat, Sumur Bandung, Bandung, 1981.

Amrullah Achmad, Dakwah Islam dan Transformasi Sosial Budaya, PLP2M, Yogyakarta, 1985.

Armahedui Mahzar, Integralisme: Sebuah Rekonstruksi Filsafat Islam, Pustaka, Bandung, 1983

Asep Muhyiddin, Metode Pengembangan Dakwah, Pustaka

Setia, Bandung, 2002

Asep S. Muhtadi, "Urgensi Pemetaan Dakwah", Berita Majalah

Warta Aljamiah, Bandung, 2010

Asep S. Muhtadi dkk, Desain dan Silabus Dakwah: Konteks dan Model Dakwah di Jawa Barat, Pemprov Jabar, Bandung, 2004

Departemen Agama, Al-Quran dan Terjemahannya, Depag, Jakarta, 2002

Agama, Jakarta, 2009

Jakarta, 2003

---------------, Pedoman Identifikasi Kebutuhan Sasaran

Dakwah Islam, Jakarta, 2003

Enjang AS, Dasar-dasar Ilmu Dakwah, Widya Pajajaran, Bandung, 2009.

Evertt M. Rogers, Memasyarakatkan Ide-ide Baru, Usaha Nasional, Surabaya, 1987. 
Haryanto, Rasulullah Way Of managing Poeople, Khalifa, Jakarta, 2008.

J.P.G. Sianipar, Manajemen Pelayanan Masyarakat, LAN RI, Jakarta, 1998

Ja'far Idris, Islam dan Perubahan Sosial, Mizan, Bandung, Cet III, 1991.

J.B.A.F., Mayor Folak, Sosiologi, Ichtiar Baru, Semarang, 1976

Judistira K. Garna, Ilmu-ilmu Sosial: Dasar, Konsep,Posisi, PPs. UNPAD, 1996

Jusman Iskandar, Teori Sosial, PPs. IAIN, Bandung, 2000

Kusmiadi, Rahmat, Teori dan teknik Perencanaan, Ilham Jaya, Bandung, 1995.

Kusmiadi, Rahmat, Teori Pemecahan Masalah dan

Pengambilan Keputusan, YBA STIA LAN,

Bandung, 1998.

Leta Rafael Levis. Komunikasi Dakwah Pedesaan. Citra Aditya Bakti, Bandung, 1996.

Nanih Machendrawati dan Agus Ahmad Syafe'i, Pengembangan Masyarakat Islam: Dari Ideologi,

Strategi Sampai Tradisi, Rosda, Bandung, 2001.

Marion B. Smith, Survey of Social Science, Hougton Mifflin Company, Sanfransisco, 1951.

M. Amin Rais, Tauhid Sosial, Mizan, Bandung, 1998

M. Jakfar Futeh, Dakwah di Era Globalisasi: Strategi Menghadapi Perubahan Sosial, AK Group, Yogyakarta, 2006.

Mohammad Sabri, Keberagamaan yang Saling Menyapa, Ittaqa Press, Yogyakarta, 1999

M Syayid M. Yusuf, At-Tamkin Li Ummati al-Islamiyah $f i$ Dhoui al-Quran al-Karim, Daarussalam, Mesir, 1997.

N. Sini Sutami K., Pemecahan Masalah dan Pengambilan Keputusan, LAN RI, Jakarta, 1998 
Nasarudin Umar, dkk., Panduan tentang Penyuluh agama Masyarakat, Ditpenais Dirjen Bimas Islam, Jakarta, 2007 Muhammad Amin, Konsep Masyarakat Islam, Fikahati Aneska, Jakarta, 1992

Sidi Ghazalba, Masyarakat Islam: Pengantar Sosiologi dan Sosiografi, Bulan Bintang, Jakarta, 1976.

Sidi Ghazalba, Islam dan Perubahan Sosiobudaya: Kajian Islam tentang Perubahan Masyarakat, Pustaka al-Husna, Jakarta, 1983.

Sidi Ghazalba, Masjid Sebagai Pusat Ibadat dan Kebudayaan, Pustaka Al-Husna, Jakarta.

Simuh (ed), Islam dan Hegemoni Sosial, Media Kita, Jakarta, 2001

Soejono Soekanto, Teori Sosiologi tentang Perubahan Sosial, Ghalia Indonesia, Jakarta.1983.

Syamsu Hilal, Gerakan Dakwah di Indonesia, Tabiatuna, Jakarta, 2003

Rochman Natawidjaja, Pendekatan-pendekatan Dakwah Kelompok, Dipenogoro, Bandung, 1989.

Romli, Dakwah Menghadapi Tantangan Baru, Jakarta: Bina Rena Pariwara, 2001

Syed Farid Alatas, Diskursus Alternatif dalam Ilmu Sosial Asia: Tanggapan terhadap Eurosentrisme, Mizan, Bandung, 2010

Syekh Faisal bin Ali Yahya Ahmad, Sistem Kaderisasai Rasulullah SAW, Pustaka Mantra, Jakarta, 1994.

Syukriadi Sambas, Risalah Pohon Ilmu Dakwah, KP Hadid, Bandung, 2004. 